\section{Plague trial verdict leaves biologists split on biodefence}

\section{Erika Check, Washington}

On 1 December, a jury in Lubbock, Texas, split the difference in its verdict on the celebrated case of plague researcher Thomas Butler. The jury cleared Butler of serious crimes relating to his handling of samples of plague bacteria, but convicted him of defrauding his university through contracts with drug companies.

In the aftermath of the case, the research community is likewise split over what its ultimate impact will be. Some insist that what they see as a vindictive prosecution of an esteemed researcher will scare many biologists away from sensitive but important work. Others say it that the case has not harmed biology — and should not alarm researchers who take care to follow the rules.

"Butler [was] innocent of the initial FBI charges relating to handling the select agent but found guilty because of peripheral information they dug up after the fact," says Stanley Falkow, a microbiologist at the University of Stanford, California, who has spoken out against the prosecution. "I'm not sure that this will calm anyone's fears certainly not mine."

But others point out that such worries have not prevented researchers from scrambling to apply for the funds that the federal government has offered for biodefence work. Ronald Atlas of the University of Louisville in Kentucky, a former president of the American Society for Microbiology, says that many scientists are eager to work on such projects.

Atlas knowledges that scientists must comply with a new array of regulations in the wake of the postal anthrax attacks in 2001. "We live in a new regulatory environment; it is our responsibility as scientists and citizens to comply with the laws and regulations," Atlas said in an e-mail. "I have not seen evidence that [the regulations] are having an adverse impact." He declined to comment specifically on the Butler case.

Butler was arrested in January after he reported that vials of plague bacteria were missing from his laboratory at Texas Tech University in Lubbock. He was charged with 15 crimes, including lying to federal agents about the vials, transporting them without the proper paperwork, and cheating on his taxes. Later, the Department of Justice charged him with 54 further crimes relating to his "shadow contracts" with drug firms.

The jury acquitted Butler of almost all of the 15 original charges - except shipping the bacteria overseas illegally — but convicted him of the fraud charges relating to his drug-company contracts. Federal judge Sam

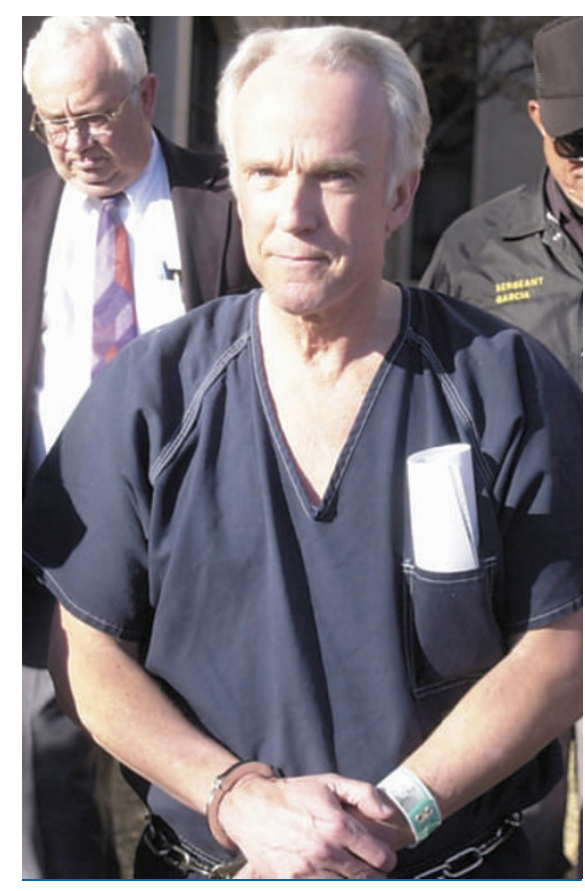

Researchers are unsure whether to draw comfort from the acquittal of Thomas Butler on most charges of illegally transporting plague (below).

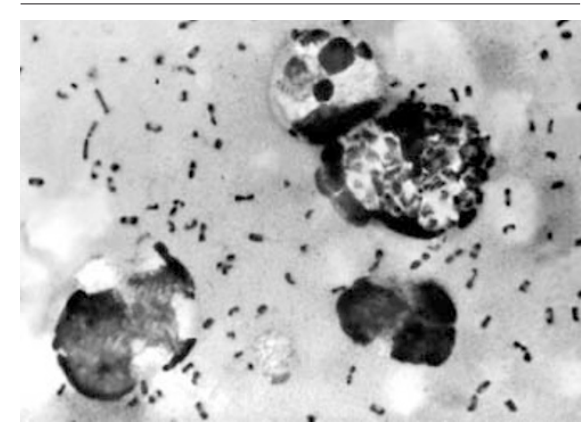

Cummings has until mid-February to set Butler's sentence. Butler's lawyers say that they will appeal against the convictions.

Regardless of the appeal outcome, Butler faces an uncertain future. On 12 December, officials at Texas Tech will meet to resume an administrative hearing that could result in his dismissal. The hearing began before Butler's trial and stemmed from disagreements between Butler and the university over financial and administrative issues. And already this year, Butler and his family have spent almost $\$ 1$ million on legal fees, his lawyer says.

But Peter Agre, a joint winner of this year's Nobel Prize in Chemistry, says that Butler should be able to continue his research career elsewhere because most scientists are sympathetic to him. "I believe that Dr Butler will survive with his name intact, but at a high cost," Agre says. "It's been a very emotionally draining year.”

\section{National Science Foundation facing budget let-down}

Geoff Brumfiel, Washington

Science advocates in the United States are disappointed at a new spending bill that will give the National Science Foundation (NSF) far less cash than was recommended in a law passed just a year ago.

The omnibus appropriations bill, which sets 2004 funding levels for much of the government, provides a $5 \%$ increase to the NSF's total budget of about $\$ 5.3$ billion. That is far less than was recommended in a bill signed by President George Bush last December, which suggested doubling the agency's budget by 2007 , by awarding $15 \%$ increases each year (see Nature 420 , 257; 2002).

"Those of us who had worked on the authorizing bill would have liked to see at least a double-digit increase," says Samuel Rankin, chair of the Coalition for National Science Funding, one of the original advocates of the 2002 legislation.

Congressional staff who worked on the 2002 bill are also disgruntled at the smaller increase set out in the 2004 budget, but say that the plan to double the NSF budget was only a suggestion. "It's not like when the [2002] bill passed we thought it would be a linear progression," says David Goldston, chief of staff at the House Committee on Science, which helped to draft the legislation. He points out that many specific initiatives supported by the committee were funded in the 2004 budget bill.

The NSF was not the only research agency to receive lacklustre funding in the 2004 budget, which was passed by the House on 8 December and is expected to be passed by the Senate early next year. The National Institutes of Health will receive an increase of just $3.2 \%$, to about $\$ 27$ billion. Janet Shoemaker, head of public affairs at the American Society for Microbiology in Washington DC, says she doubts that the president's budget proposal for 2005, to be released in February, will be much more generous.

In the 2004 bill, NASA's budget was held at $\$ 15$ billion, but money for research was trimmed by $0.4 \%$, partly because of budget pressure arising from the loss of the shuttle Columbia in February. The research budget of the National Institute of Standards and Technology also fell by $4 \%$, to $\$ 506$ million. The Department of Energy's Office of Science fared better, winning a $3.8 \%$ increase to $\$ 3.2$ billion. Much of that money will go towards research on nuclear fusion, computing and biology. 